\title{
Knowledge, attitude and practice of progestin-only emergency contraceptives among female students of Jimma Teachers Training College, Jimma, Ethiopia
}

\section{Bahir K. A/Warri ${ }^{1}$ and Tadesse G. Gurmu ${ }^{2}$}

Ghana Med J 2018; 52(4): 183-188 doi: http://dx.doi.org/10.4314/gmj.v52i4.4

\author{
${ }^{1}$ Jimma University Medical Center, Jimma, Ethiopia \\ ${ }^{2}$ School of Pharmacy, Faculty of Health Sciences, Jimma University, Jimma, Ethiopia \\ Corresponding author: Mr.Tadesse G. Gurmu \\ Conflict of interest: None declared \\ E-mail: gudetatadesse@gmail.com
}

\section{SUMMARY}

Background: Emergency contraception (EC) is the safest strategy for prevention of unintended pregnancy following unsafe sex provided that users have sufficient knowledge \& awareness of EC.

Objective: The main objective of this study was to assess the knowledge, attitude, and practice of progestin-only emergency contraceptives.

Methods: Retrospective cross-sectional study was conducted from February 16 to April 18, 2017, among students of Jimma teacher's training college. Chi-square test was run to identify the association between variables. Variables with the critical value $\mathrm{P}<0.05$ at CI of $95 \%$ were considered as statistically significant.

Results: A total of 270 female students were involved in the study; of which $53.70 \%$ of them had knowledge about ECs. A significant association was found between knowledge on ECs \& age distribution $(\mathrm{p}<0.001)$ and also the sexual activity of the participants $(\mathrm{p}=0.013)$.More than half of the respondents agreed that widespread use of ECs would increase the prevalence of HIV/ AIDS and other sexually transmitted diseases (STIs). Of the total study participants, $121(44.81 \%)$ have used ECs and the utilization practice has a significant association with age distribution $(\mathrm{p}<0.001$ and religion of the study participants $(\mathrm{p}=0.002)$.

Conclusion: Generally, nearly half of the study participants had knowledge about ECs and used EC at least once in their lifetime. Most of the students agreed that relying on EC pills and its accessibility would promote the spread of HIV/AIDS and STIs.

Funding: The study was conducted with the financial support of Jimma University

Keywords: Knowledge, emergency contraceptives, attitude, practice

\section{INTRODUCTION}

Globally, many young women and men suffer a disproportionate share of unplanned pregnancies, sexually transmitted diseases (STD) including HIV and other serious reproductive health problems. ${ }^{1}$ The Guttmacher institute, a leading research and policy organization in the USA identified that 213 million pregnancies occurred worldwide in 2012 of which $40 \%$ pregnancies were unintended and increased by $1.2 \%$ from 2008 to 2012. ${ }^{2}$ The rate of unintended pregnancy remains high in developing countries \& significant percentage ended in abortion. One study indicated that in every 1000 sexually active females, 86 unintended pregnancies occur in sub-Saharan Africa. ${ }^{3}$ Emergency contraception is one of the contraceptive strategies employed to prevent unplanned pregnancy following an episode of unprotected intercourse during the fertile period.
Emergency contraception is important especially for women at risk of pregnancy but not using a regular method by providing a bridge to use an ongoing contraceptive method. Although emergency contraceptives do not protect against sexually transmitted infection (STIs), they do offer reassurance to women who rely on condoms for protection against pregnancy in case of condom slippage or breakage. Intrauterine contraceptive devices (IUCDs) and oral contraceptive pills are mainly used as emergency contraceptives. Oral contraceptive pills have $75-85 \%$ efficacy in preventing pregnancy when used within 72 hours after unsafe sexual intercourse. ${ }^{4,5}$ In Uganda, a study conducted in 2006 indicates the rate of maternal death especially the death of young females as a result of unsafe abortion was found to be high at 505/100000 live births and the contraception use rate was only $23 \%$. 
The study concluded that the knowledge and attitudes of the females about the emergency contraception was very low. ${ }^{6}$ In the same manner in South Africa, only $30 \%$ of women heard about emergency contraception plus most of the respondents who were aware of emergency contraception did not know about the appropriate recommended time to take emergency contraception after unprotected sexual intercourse. ${ }^{7}$

In Ethiopia, in the past decade, the rate of maternal death because of unsafe abortion and unwanted pregnancy was found to be high. Even though awareness among the population was very low, the Ethiopian federal ministry of health adopted the provision of emergency contraception as one of the strategies to mitigate problems to minimize the maternal morbidity, mortality and its complications.

Unsafe abortion was the leading causes attributed to the high number of maternal morbidity and mortality. ${ }^{8}$ In order to mitigate this problem, the Ethiopian federal ministry of health has allowed the distribution of EC in drug stores and the provision of safe abortion services in medical setup for those who demand the service under certain conditions such as rape, incest, sexual violence, etc. ${ }^{9}$ However scientific researches regarding the utilization pattern, the knowledge, and attitude of the users were limited to certain parts of the country.

Therefore, the aim of this study was to assess the knowledge, attitude, and practice of emergency contraception among female students of Jimma Teachers Training College. The objectives of the study were:

(a) to assess the knowledge of college students on emergency contraceptives,

(b) to determine the attitude of students towards emergency contraceptives use,

(c) to determine the prevalence of emergency contraceptives use among college students and

(d) to identify factors associated with emergency contraceptives use and knowledge on emergency contraceptives.

\section{METHODS}

Retrospective cross-sectional study was conducted at Jimma Teachers Training College (JTTC). The college is found in Jimma town $2 \mathrm{~km}$ away from Jimma university main campus to the northeast.

Jimma town is located in the southwest of Ethiopia, 345 $\mathrm{km}$ away from Addis Ababa, the capital city of Ethiopia. The college hosts 9 departments in diploma program namely; geography, history, civics \& ethics, chemistry, biology, mathematics, physics, afan Oromo \& English. The college receives approximately 500-700 new students each year and graduates 500 .
Currently, the college has a total of 1573 students (856 males \& 717 females). The sample size was determined using a single population proportion formula ${ }^{10}$ The sample size computed from the formula was 384 .

Since the sampling frame was relatively small $(\mathrm{N}=717$ female students, the study was conducted on female students), the above estimate was adjusted using finite population correction formula. ${ }^{10}$ By considering nonresponse rate, $10 \%$ contingency was added $\&$ the final sample size became 275. Since the students were of different batches (level of study) and departments, stratified sampling technique was used to classify the students based on their batches and departments.

Then simple random sampling technique using lottery method was applied to select the study units from each stratum until the required sample size was achieved. The necessary data were gathered using structured questionnaires. The statistical package for the social sciences (SPSS) version 20 was used to analyze the data. The association between dependent and independent variables was determined by running chi-square test and variables with critical value $\mathrm{p}<0.05$ was considered as statistically significant. Ethical approval was granted from the ethical review committee of Jimma university school of pharmacy (Ref. No. Sch/P/75/2017).

The data collection permission was then obtained from Jimma Teachers Training College by submitting a letter of collaboration (Ref. No. Sch/P/76/2017) written from Jimma University School of Pharmacy along with the ethical clearance. Written informed consent was obtained from the study participants after explaining the purpose of the study and they were also assured that the collected data would be kept confidential.

\section{RESULTS}

From the total of 275 questionnaires administered to the students, 270 questionnaires were completely filled with a response rate of $98 \%$. Majority of the students were within the age range of 20 to 24. Most of the students, $225(83.33 \%)$ were unmarried (i.e. single and those who have a boyfriend).

Of the total participants, $190(70.37 \%)$ were at the level one educational status and about 142 (52.6\%) were Muslims. One hundred ninety-four $(71.8 \%)$ of the total participants were sexually active (Table 1).

Regarding information on ECPs and source of information, about $55 \%$ of the total participants had information about emergency contraceptives (ECPs). Other major sources of their information were their friends $127(43.1 \%)$, health education $76(26.2 \%)$, and radio 61 (17.12\%) (Figure1). 
Table 1 The socio-demographic characteristics of the study participants $(\mathrm{n}=270)$

\begin{tabular}{|l|l|}
\hline Characteristics & Frequency (\%) \\
\hline Age & \\
\hline $\mathbf{1 5}-19$ & $72(26.67)$ \\
\hline $\mathbf{2 0 - 2 4}$ & $131(48.51)$ \\
\hline $\mathbf{2 5 - 2 9}$ & $59(21.85)$ \\
\hline $\mathbf{3 0 - 3 4}$ & $8(2.96)$ \\
\hline Total & $270(100)$ \\
\hline Marital status & \\
\hline Has a boy-friend & $52(19.26)$ \\
\hline Single & $173(64.07)$ \\
\hline Married & $41(15.18)$ \\
\hline Divorced & $3(1.11)$ \\
\hline Widowed & $1(0.37)$ \\
\hline Total & $270(100)$ \\
\hline level of study & \\
\hline level I & $190(70.37)$ \\
\hline level II & $69(25.56)$ \\
\hline level III & $11(4.07)$ \\
\hline Total & $270(100)$ \\
\hline Religion & \\
\hline Orthodox & $142(52.59)$ \\
\hline Muslim & $75(27.78)$ \\
\hline Protestant & $25(9.26)$ \\
\hline Catholic & $24(8.89)$ \\
\hline *other (specify) & $4(1.48)$ \\
\hline Total & $270(100)$ \\
\hline Sexual activity & $194(71.85)$ \\
\hline Sexually active & $76(28.15)$ \\
\hline Sexually not active & $270(100)$ \\
\hline Total & \\
\hline Jehovah's, Adventists, & \\
\hline
\end{tabular}

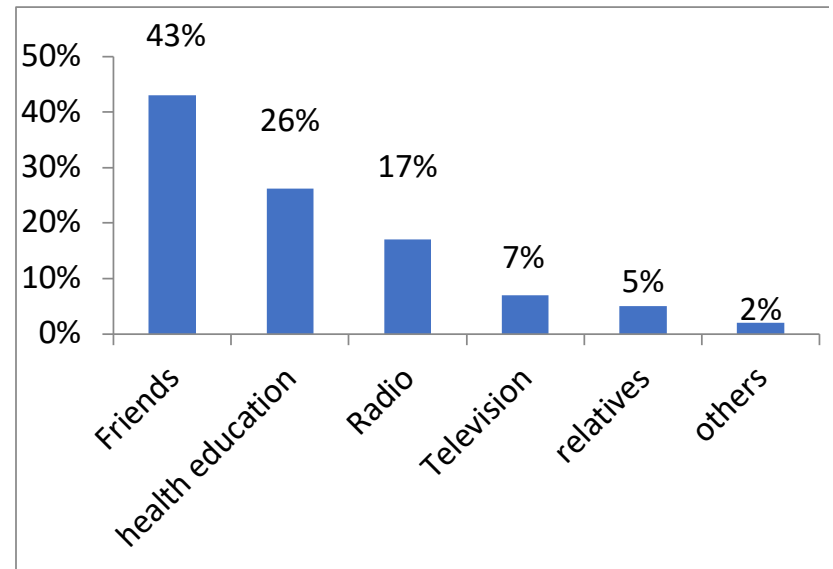

Figure 1 Sources of information about emergency contraceptives as reported by participants $(n=270)$.

The majority of the study participants, 131 (48.6\%) reported that the correct recommended time to take emergency contraceptives to be within 72 hours. One hundred forty $(51.8 \%)$ of the participants stated that the recommended dose and frequency of administration to be one tablet two times 12 hours apart (Table 2).
Table 2 Knowledge regarding the dosage regimen of ECPs among study participants $(n=270)$

\begin{tabular}{|l|l|}
\hline Recommended time to take ECPs & Frequency (\%) \\
\hline Within 24 hours after sex & $63(23.4)$ \\
\hline Within 48 hours after sex & $26(9.5)$ \\
\hline Within 72 hours after sex & $131(48.6)$ \\
\hline I don't know & $50(18.6)$ \\
\hline Total & $270(100)$ \\
\hline Recommended dose and frequency of administration \\
\hline One tablet two times 12 hours apart & $140(51.8)$ \\
\hline One tablet two times 24 hours a part & $31(11.5)$ \\
\hline I don't know & $99(36.7)$ \\
\hline Total & $270(100)$ \\
\hline
\end{tabular}

Among $55 \%$ of the respondents who have heard of ECPS, $52.01 \%$ of them knew that ECPS can be obtained from pharmacy (Figure 2).

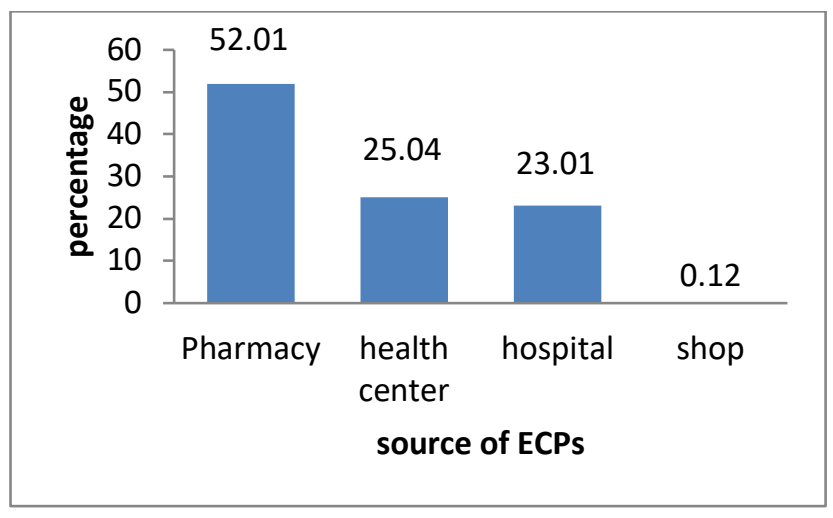

Figure 2 Sources of ECPs for those respondents, who have heard of ECPs among study participants $(n=270)$

The study indicated that $145(53.70 \%)$ of the total respondents who heard about emergency contraceptives had knowledge about emergency contraceptives.

From the chi-square test result, knowledge about emergency contraceptives had a significant association with the age distribution $(\mathrm{p}<0.001)$ and sexual activity of the study participants $(p=0.013)$ (table 3$)$. With regard to the attitude of respondents, $188(69.63 \%)$ of them had a plan of using emergency contraceptives (ECPs) and also promote others to use if unintended sexual intercourse occurs.

One hundred fifty $(55.6 \%)$ of the respondents believed that widespread use of ECPs would increase the prevalence of HIV/ AIDS and other sexually transmitted diseases (STIs), 147 (54.4\%) of the respondents thought that availability and accessibility of ECPs may promote sexual risk-taking behavior, $146(54.1 \%)$ of them did not think of ECPs as one way to induce abortions. 
Eighty-seven $(32.2 \%)$ of the respondents were not sure that whether ECPs are safer than oral contraceptive pills (OCPs) and $129(47.8 \%)$ of respondents were not sure that if ECPS would affect ongoing regular methods of contraception. (Table 4).

Table 3 Association between knowledge about emergency contraceptives and socio-demographic characteristics of the study participants

\begin{tabular}{|c|c|c|c|c|}
\hline \multirow{2}{*}{$\begin{array}{l}\text { Variables } \\
\text { Age }\end{array}$} & \multicolumn{3}{|c|}{ Knowledge about ECPs, } & \multirow{2}{*}{$\begin{array}{l}\begin{array}{l}\text { Associa- } \\
\text { tion }\end{array} \\
\mathrm{X}^{2}=57.4 \\
\mathrm{P}=0.000 \\
\mathrm{P}<0.05\end{array}$} \\
\hline & $\begin{array}{l}\text { Yes } \\
(n=145) \\
\text { Frequency } \\
(\%)\end{array}$ & $\begin{array}{l}\begin{array}{l}\text { No } \\
(n=125)\end{array} \\
\text { Frequency } \\
(\%)\end{array}$ & $\begin{array}{l}\quad \text { Total } \\
(n=270) \\
\text { Frequency } \\
(\%)\end{array}$ & \\
\hline $15-19$ & $15(20.83)$ & $57(79.17)$ & $72(26.67)$ & \\
\hline $20-24$ & $74(56.49)$ & $57(43.51)$ & $131(48.51)$ & \\
\hline 25-30 & $51(86.44)$ & $8(13.56)$ & $59(21.85)$ & \\
\hline $31-49$ & $5(62.5)$ & $3(37.5)$ & $8(2.96)$ & \\
\hline \multicolumn{5}{|l|}{ Religion } \\
\hline Orthodox & $83(58.45)$ & $59(44.55)$ & $142(52.59)$ & \multirow{5}{*}{$\begin{array}{l}X^{2}=8.23 \\
P=0.084 \\
P>0.05\end{array}$} \\
\hline Muslim & $33(44)$ & $42(56)$ & $75(27.78)$ & \\
\hline $\begin{array}{l}\text { Protestan } \\
\text { t }\end{array}$ & $14(56)$ & $11(44)$ & $25(9.26)$ & \\
\hline Catholics & $11(45.83)$ & $13(54.17)$ & $24(8.89)$ & \\
\hline Others & $4(100)$ & $0(0)$ & $4(1.48)$ & \\
\hline \multicolumn{5}{|c|}{ Marital status } \\
\hline $\begin{array}{l}\text { Has a } \\
\text { boyfriend }\end{array}$ & $32(61.54)$ & $20(38.46)$ & $52(19.26)$ & \multirow{5}{*}{$\begin{array}{l}X^{2}=3.25 \\
P=0.516 \\
P>0.05\end{array}$} \\
\hline Single & $87(50.29)$ & $86(49.71)$ & $173(64.07)$ & \\
\hline Married & $23(56.10)$ & $18(43.90)$ & $41(15.18)$ & \\
\hline Divorced & $2(66.67)$ & $1(33.33)$ & $3(1.11)$ & \\
\hline Widowed & $1(100)$ & $0(0)$ & $1(0.37)$ & \\
\hline \multicolumn{5}{|c|}{ Level of study } \\
\hline Level I & $94(49.47)$ & $96(50.53)$ & $\begin{array}{l}190 \\
(70.37)\end{array}$ & \multirow{3}{*}{$\begin{array}{l}X^{2}=5.03 \\
P=0.081 \\
P>0.05\end{array}$} \\
\hline Level II & $43(62.32)$ & $26(37.68)$ & $69(25.56)$ & \\
\hline Level III & $8(72.73)$ & $3(27.27)$ & $11(4.07)$ & \\
\hline \multicolumn{5}{|c|}{ Sexual activity } \\
\hline $\begin{array}{l}\text { Sexually } \\
\text { active }\end{array}$ & $95(48.97)$ & $99(51.03)$ & $194(71.85)$ & \multirow{2}{*}{$\begin{array}{l}X^{2}=6.21 \\
P=0.013 \\
P<0.05\end{array}$} \\
\hline $\begin{array}{l}\text { Sexually } \\
\text { not active }\end{array}$ & $50(65.79)$ & $26(34.21)$ & $76(28.15)$ & \\
\hline
\end{tabular}

Concerning the use of ECPs, $44.81 \%$ of the respondents have used emergency contraception at least once in their lifetime and the majority of them were within the age range of 20-24 (58\%).

Emergency contraception utilization has a statistically significant association with age $(\mathrm{p}<0.001)$ and religion of the respondents $(\mathrm{p}=0.002)$ (Table 5$)$.

The study also revealed that majority, about $77.22 \%$ of them preferred to use a condom and some of them preferred emergency contraceptives during sexual intercourse. The main reasons for the respondents who had preferred condom were the advantage of condom in preventing both pregnancy and sexually transmitted diseases (STDs).
Table 4 Attitudes towards ECPs among the female students

\begin{tabular}{|c|c|c|c|}
\hline \multirow[t]{2}{*}{ Attitudes towards ECPS } & Yes & No & Not sure \\
\hline & $\begin{array}{l}\text { Frequency } \\
(\%)\end{array}$ & $\begin{array}{l}\text { Frequency } \\
(\%)\end{array}$ & $\begin{array}{l}\text { Frequency } \\
(\%)\end{array}$ \\
\hline $\begin{array}{l}\text { If I have unintended } \\
\text { sexual intercourse, I } \\
\text { would use ECPs and } \\
\text { also promote others to } \\
\text { use if they commit unde- } \\
\text { sired sex. }\end{array}$ & $188(69.63)$ & $34(12.6)$ & $48(17.8)$ \\
\hline $\begin{array}{l}\text { Wide spread use of } \\
\text { ECPs will increase the } \\
\text { prevalence of HIV/ } \\
\text { AIDS and other STIs. }\end{array}$ & $150(55.6)$ & $65(24.1)$ & $55(20.4)$ \\
\hline $\begin{array}{l}\text { Availability and accessi- } \\
\text { bility of ECPs may } \\
\text { promote sexual risk- } \\
\text { taking behavior }\end{array}$ & $147(54.4)$ & $58(21.5)$ & $65(24.1)$ \\
\hline $\begin{array}{l}\text { Emergency contracep- } \\
\text { tion is one way of abor- } \\
\text { tion }\end{array}$ & 35 (13) & $146(54.1)$ & $89(33)$ \\
\hline $\begin{array}{l}\text { ECPs are safer than } \\
\text { OCPs }\end{array}$ & $59(21.9)$ & $124(45.9)$ & $87(32.2)$ \\
\hline $\begin{array}{l}\text { ECPS will affect ongo- } \\
\text { ing regular methods of } \\
\text { contraception negatively }\end{array}$ & 78 (28.9) & $63(23.3)$ & $129(47.8)$ \\
\hline
\end{tabular}

Table 5 Association between ECPs utilization and socio-demographic characteristics of the study participants

\begin{tabular}{|c|c|c|c|c|}
\hline Variables & EC & utilization & & Association \\
\hline Age & $\begin{array}{l}\text { Used } \\
(n=121) \\
\text { Frequency } \\
(\%)\end{array}$ & $\begin{array}{l}\begin{array}{l}\text { Not used } \\
(n=149)\end{array} \\
\text { Frequency } \\
(\%)\end{array}$ & $\begin{array}{l}\text { Total } \\
(\mathbf{n}=\mathbf{2 7 0}) \\
\text { Frequency } \\
(\%)\end{array}$ & \multirow{5}{*}{$\begin{array}{l}\mathrm{X}^{2}=36.1 \\
\mathrm{P}=0.000 \\
\mathrm{P}<0.05\end{array}$} \\
\hline 15-19 & $11(15.28)$ & $61(84.72)$ & $72(26.67)$ & \\
\hline $20-24$ & $76(58)$ & $55(42)$ & $131(48.51)$ & \\
\hline 25-30 & $29(49.15)$ & $30(50.85)$ & $59(21.85)$ & \\
\hline $31-49$ & $5(62.50)$ & $3(37.50)$ & $8(2.96)$ & \\
\hline \multicolumn{5}{|l|}{ Religion } \\
\hline Orthodox & $72(50.70)$ & $70(49.30)$ & $142(52.59)$ & \multirow{5}{*}{$\begin{array}{l}\mathrm{X}^{2}=16.7 \\
\mathrm{P}=0.002 \\
\mathrm{P}<0.05\end{array}$} \\
\hline Muslim & $36(48)$ & $39(52)$ & $75(27.78)$ & \\
\hline Protestant & $2(8)$ & $23(92)$ & $25(9.26)$ & \\
\hline Catholics & $10(41.67)$ & $14(58.33)$ & $24(8.89)$ & \\
\hline Others & $1(25)$ & $3(75)$ & $4(1.48)$ & \\
\hline \multicolumn{5}{|l|}{$\begin{array}{l}\text { Marital } \\
\text { status }\end{array}$} \\
\hline $\begin{array}{l}\text { Has a boy- } \\
\text { friend }\end{array}$ & $32(61.54)$ & $20(38.46)$ & $52(19.26)$ & \multirow{5}{*}{$\begin{array}{l}\mathrm{X}^{2}=9.11 \\
\mathrm{P}=0.058 \\
\mathrm{P}>0.05\end{array}$} \\
\hline Single & $72(41.62)$ & $101(58.38)$ & $173(64.07)$ & \\
\hline Married & $15(36.59)$ & $26(63.41)$ & $41(15.18)$ & \\
\hline Divorced & $2(66.67)$ & $1(33.33)$ & $3(1.11)$ & \\
\hline Widowed & $0(0)$ & $1(100)$ & $1(0.37)$ & \\
\hline \multicolumn{5}{|l|}{$\begin{array}{l}\text { Level of } \\
\text { study }\end{array}$} \\
\hline Level I & $79(41.58)$ & $111(58.42)$ & $190(70.37)$ & \multirow{3}{*}{$\begin{array}{l}X^{2}=2.74 \\
P=0.255 \\
P>0.05\end{array}$} \\
\hline Level II & $36(52.17)$ & $\begin{array}{l}33 \\
(47.83 \%)\end{array}$ & $69(25.56)$ & \\
\hline Level III & $6(54.55)$ & $5(45.45)$ & $11(4.07)$ & \\
\hline \multicolumn{5}{|l|}{$\begin{array}{l}\text { Sexual } \\
\text { activity }\end{array}$} \\
\hline $\begin{array}{l}\text { Sexually } \\
\text { active }\end{array}$ & 93 (47.94) & $101(52.06)$ & $194(71.85)$ & \multirow{2}{*}{$\begin{array}{l}X^{2}=2.72 \\
P=0.099 \\
P>0.05\end{array}$} \\
\hline $\begin{array}{l}\text { Sexually } \\
\text { not active }\end{array}$ & $28(36.84)$ & $48(63.16)$ & $76(28.15)$ & \\
\hline
\end{tabular}


On the other side, those groups who preferred emergency contraception over other methods to prevent unplanned pregnancy was the trust they had with their partners (Table 6).

Table 6 Reasons for preference of ECPS and condom to prevent unintended pregnancy among the participants

\begin{tabular}{|l|l|}
\hline Reasons to prefer condom & Frequency (\%) \\
\hline It can prevent both pregnancy and STDs & $244(77.22)$ \\
\hline $\begin{array}{l}\text { It is more available than ECPs } \\
\text { I don't want to use ECPs/OCPs for fear of } \\
\text { side effects }\end{array}$ & $43(13.61)$ \\
\hline \begin{tabular}{l} 
I don't know about ECPs \\
\hline Others *
\end{tabular} & $8(2.53)$ \\
\hline Total & $6(1.9)$ \\
\hline Reason to prefer ECPS & $316(100)$ \\
\hline Trust each other & $240(39.93)$ \\
\hline $\begin{array}{l}\text { It increase sexual pleasure } \\
\text { Taking ECPs is convenient than OCPs }\end{array}$ & $123(20.46)$ \\
\hline $\begin{array}{l}\text { ECPs can be used as replacements for } \\
\text { OCPs }\end{array}$ & $95(15.8)$ \\
\hline $\begin{array}{l}\text { My partner do not accept in using Con- } \\
\text { dom }\end{array}$ & $35(5.82)$ \\
\hline $\begin{array}{l}\text { Others** } \\
\text { Total }\end{array}$ & $2(0.33)$ \\
\hline * cost, ** Allergy, culture & $601(100)$ \\
\hline
\end{tabular}

\section{DISCUSSION}

Emergency contraception is a method of contraception that prevents pregnancy by preventing or delaying ovulation. However, emergency contraception pills cannot prevent sexually transmitted diseases and also it should not be used as a regular method of contraception..$^{11}$ This chapter discusses the knowledge, attitude, and practice of emergency contraception among female college students.

Accordingly, the current study revealed that around 55 $\%$ of the study participants had information about emergency contraception and the majority of them obtained the information from friends $43 \%$, and health education $26 \%$. There is a slight difference compared to the report obtained from the study conducted among Addis Ababa University female students where around $43.5 \%$ of the students had heard about emergency contraception and also obtained the information mostly from friends and media. ${ }^{8}$

In the present study, concerning dosage regimen of emergency contraception pills, it was identified that around half $(48.6 \%)$ of the respondents knew the recommended time for emergency contraception pills to be within 72 hours, and $51.8 \%$ of them knew the dose and frequency of administration to be one tablet two times 12 hours apart. This finding slightly resembles the result from the study conducted in South Africa, $42 \%$ of the respondents know the correct time of taking emergency contraceptives after unprotected sexual intercourse ${ }^{12}$ and a little bit higher than the study done among Swe- dish women where only less than $38 \%$ of the participants knew the recommended time frames for use. ${ }^{13}$

The discrepancy between the result of current study and that of Swedish might be the difference between the educational backgrounds of the study participants where the present study was done on female college students and the study conducted in Swedish includes all type of females.

Majority of the current study participants reported that emergency contraception can be obtained from pharmacy $52.01 \%$, health centers $25.04 \%$ and hospitals $23.01 \%$. These findings were somewhat different in magnitude compared to the previous study conducted in Jamaica where the majority of the students knew that ECPs would be obtained from pharmacies $87 \%$, health centers $69 \%$ and hospitals $60 \%{ }^{14}$ The possible reasons might be the socio-cultural difference between the two countries, Ethiopia and Jamaica.

Concerning the attitude of the respondents towards emergency contraception, the present study identified that some of the students had a plan of using emergency contraceptives (ECPs) and also promote others to use if unintended sexual intercourse occurs. They also believed that the widespread use of ECPs would increase the prevalence of HIV/ AIDS and other STIs. In the same way, they agreed that the availability and accessibility of ECPs may promote sexual risk-taking behavior. On the other hand, more than half of the study participants did not agree that ECPs as one way to induce abortions. Similar reports were obtained from the crosssectional study done among Addis Ababa University and Jimma University female students. ${ }^{8}, 15$

The current study also showed that $44.81 \%$ of the respondents had a history of emergency contraception use and the utilization of ECPs had a significant association with the age and religion of the students $(\mathrm{p}<0.05)$.This finding is higher than the report obtained from the study done among students in Hong Kong where only $10 \%$ of the respondents had used emergency contraception in the attempt to prevent unintended pregnancy. However, like the current study the utilization practice had a significant association with the age of the respondents. ${ }^{16}$ The difference in the practice of ECPs might be because of socio-cultural and awareness among females in Hong Kong and the current study area.

\section{CONCLUSION}

About half of the study participants had knowledge about ECs and used EC at least once in their lifetime. Most of the students agreed that relying on EC pills and its accessibility would promote the spread of HIV/AIDS and STIs. 


\section{ACKNOWLEDGEMENT}

The authors would like to express special thanks to Jimma University for the facilitation of the study. We would also like to acknowledge the administrative office of Jimma Teachers College.

\section{REFERENCES}

1. World Health Organization. Preventing HIV/AIDS and Promoting Sexual Health among Especially Vulnerable Young People. Geneva, Switzerland; 2002 [cited 2017 Jul 19]. p. 1-47. Available from: http://www.who.int/hiv/pub/prev_care/en/vulnerabl eyp.pdf

2. AlRifai A. Assessment of Safe and Unsafe Abortion among Palestinian Women in Hebron Governorate in Southern West Bank- Palestine. 2015 [cited 2017 Jul 20]. p. 77. Available from: http://www.safeabortionwomensright.org/wpcontent/uploads/2016/05/Family-Planning-andProtection-Association-Final.pdf

3. Ali SA, Ali SA. Unmet need for Contraception and unintended Pregnancies among women of reproductive age group : A situation analysis. Elect Med J. 2014;2(3):259-65.

4. Shiferaw BZ, Gashaw BT, Tesso FY. Factors associated with utilization of emergency contraception among female students in Mizan - Tepi University, South West. BMC Res Notes. BioMed Central; 2015;15 (8) 1-10.

5. Abate M, Assefa N, Alemayehu T. Knowledge, Attitude, Practice and Determinants Emergency of Contraceptive Use among Women Seeking Abortion Services in Dire Dawa, Ethiopia. PLoS Med. 2014;9(10):1-7.

6. Byamugisha JK, Mirembe FM, Gemzell-danielsson EFK. Emergency Contraception and Fertility awareness among University Students in Kampala, Uganda. Afr Health Sci. 2006;6(4):194-200.

7. Myer L, Mlobeli R, Cooper D, Smit J, Morroni C. Knowledge and use of emergency contraception among women in the Western Cape province of
South Africa: a cross-sectional study. BMC Womens Health. 2007;7(7):1-7.

8. Tamire W, Enqueselassie F. Knowledge, attitude, and practice on emergency contraceptives among female university students in Addis. Ethiop $J$ Health Dev. 2007;21(2):111-6.

9. Hamdela B, Abebe G, Tilahun T. Unwanted Pregnancy and Associated Factors among Pregnant Married Women in Hosanna Town, Southern. Hindawi J Pregnancy. 2014;7(6):1-8.

10. Sierra Systems Consultants. Estimation and sample size determination for finite populations. 1994 [cited 2017 Jun 29]. p. 18-21. Available from: http://41.89.101.166:8080/xmlui/bitstream/handle/1 23456789/4382/cdch08_part1.pdf?sequence $=8$ \&is Allowed $=\mathrm{y}$

11. Ahmed FA, Moussa KM, Petterson KO, Asamoah BO. Assessing knowledge, attitude, and practice of emergency contraception: a cross- sectional study among Ethiopian undergraduate female students. BMC Public Health. 2012;22(3):1-9.

12. Maharaj P, Rogan M. Emergency contraception in South Africa: a literature review. Eur J Contracept Reprod Health Care. 2008;13(4):351-61.

13. Halldén BM, Christensson K, Olsson P. Early abortion as narrated by young Swedish women. Scand J Caring Sci. 2009;23(2):243-50.

14. Sorhaindo A, Becker D, Fletcher H, Garcia SG. Emergency contraception among university students in Kingston, Jamaica : a survey of knowledge , attitudes , and practices. Contraception. 2002;66 (2):261-8.

15. Tajure N. Knowledge, Attitude and Practice of Emergency Contraception among Graduating Female Students of Jimma University, Southwest Ethiopia. Ethiop J Heal Sci. 2010;20,(2):91-7.

16. Lee, Wai, Lai, Ho. Women's knowledge of and attitudes towards emergency contraception in Hong Kong: questionnaire survey. Hong Kong Med J. 2009;5(4):349-52.0 